Scientific Note

\title{
First record of Belminus laportei Lent, Jurberg \& Carcavallo, 1995 (Hemiptera: Reduviidae: Triatominae) from French Guiana
}

\author{
Primer registro de Belminus laportei Lent, Jurberg y Carcavallo, 1995 (Hemiptera: \\ Reduviidae: Triatominae) en la Guayana Francesa \\ Hélcio R. Gil-Santana ${ }^{1}$ and Jader de Oliveira ${ }^{2,3^{+}}$
}

\begin{abstract}
${ }^{1}$ Laboratório de Diptera, Instituto Oswaldo Cruz, Av. Brasil, 4365, 21040-360, Rio de Janeiro, Brazil. E-mail: helciogil@uol.com.br; helciogil@ioc.fiocruz.br. ${ }^{2}$ Universidade de São Paulo, Faculdade de Saúde Pública, Laboratório de Entomologia em Saúde Pública, São Paulo, SP, Brasil. ${ }^{3}$ Universidade Estadual Paulista "Julio de Mesquita Filho", Faculdade de Ciências Farmacêuticas, Laboratório de Parasitologia, Araraquara, SP, Brasil.驺*jdr.oliveira@hotmail.com
\end{abstract}

\section{ZooBank: urn:lsid:zoobank.org:pub:2DE22BA3-296A-4580-B36E-4E903725D78A https: / / doi.org/10.35249/ rche.47.3.21.02}

\begin{abstract}
The occurrence of Belminus laportei Lent, Jurberg \& Carcavallo, 1995 (Hemiptera: Reduviidae: Triatominae) in French Guiana is reported for the first time. A triatomine specimen collected in Bélizon, French Guiana was found to be a female of Belminus laportei, a species known so far only from Pará State, Brazil. The discovery of this species broadens its known geographic distribution and increases the number of triatomines recorded from the French Guiana to fifteen.
\end{abstract}

Key words: Biogeography; Bolboderini; Chagas disease; Heteroptera.

Resumen. Se informa por primera vez la presencia de Belminus laportei Lent, Jurberg y Carcavallo, 1995 (Hemiptera: Reduviidae: Triatominae) en la Guayana Francesa. Se descubrió que un espécimen de triatomino recolectado en Bélizon, Guayana Francesa, era una hembra de Belminus laportei, una especie que hasta ahora solo era conocía del estado de Pará, Brasil. El hallazgo de esta especie amplía su distribución geográfica conocida e incrementa a quince el número de triatominos registrados para Guayana Francesa.

Palabras clave: Biogeografía; Bolboderini; enfermedad de Chagas; Heteroptera.

The species included in the subfamily Triatominae (Hemiptera: Heteroptera: Reduviidae) are blood-sucking bugs which are proved or potential vectors of Chagas disease caused by the protozoan Trypanosoma cruzi (Chagas, 1909) (Kinetoplastida: Trypanosomatidae) (Lent and Wygodzinsky 1979; Galvão 2014). This disease is still of major importance in Public Health in Latin America (Monteiro et al. 2018).

Currently, Triatominae includes more than 150 species distributed in five tribes. The tribe Bolboderini has four genera, among them, Belminus Stål, 1859 includes eight species distributed in some countries of Central and South America (Lent and Wygodzinsky 1979; Lent et al. 1995; Galvão et al. 2003; Galvão and Angulo 2006; Sandoval et al. 2007; Zhao et al . 2021; Costa et al. 2021).

Belminus laportei Lent, Jurberg \& Carcavallo, 1995 was described based on five males,

Received 28 May 2021 / Accepted 2 July 2021 / Published online 30 July 2021 Responsible Editor: José Mondaca E. 
two (or three) females and three nymphs collected in three somewhat near localities in the state of Pará, namely: Utinga (Belém) (male holotype), Monte Dourado (a female paratype named as "allotype"), and Jari (four male paratypes and one or two female paratypes and three nymphs) (Lent et al. 1995). The latter authors did not make clear the actual number of female paratypes, because although they mentioned " 2 females" as such, in their list of examined specimens only a female from Jari was recorded. After their description there was no further record of $B$. laportei.

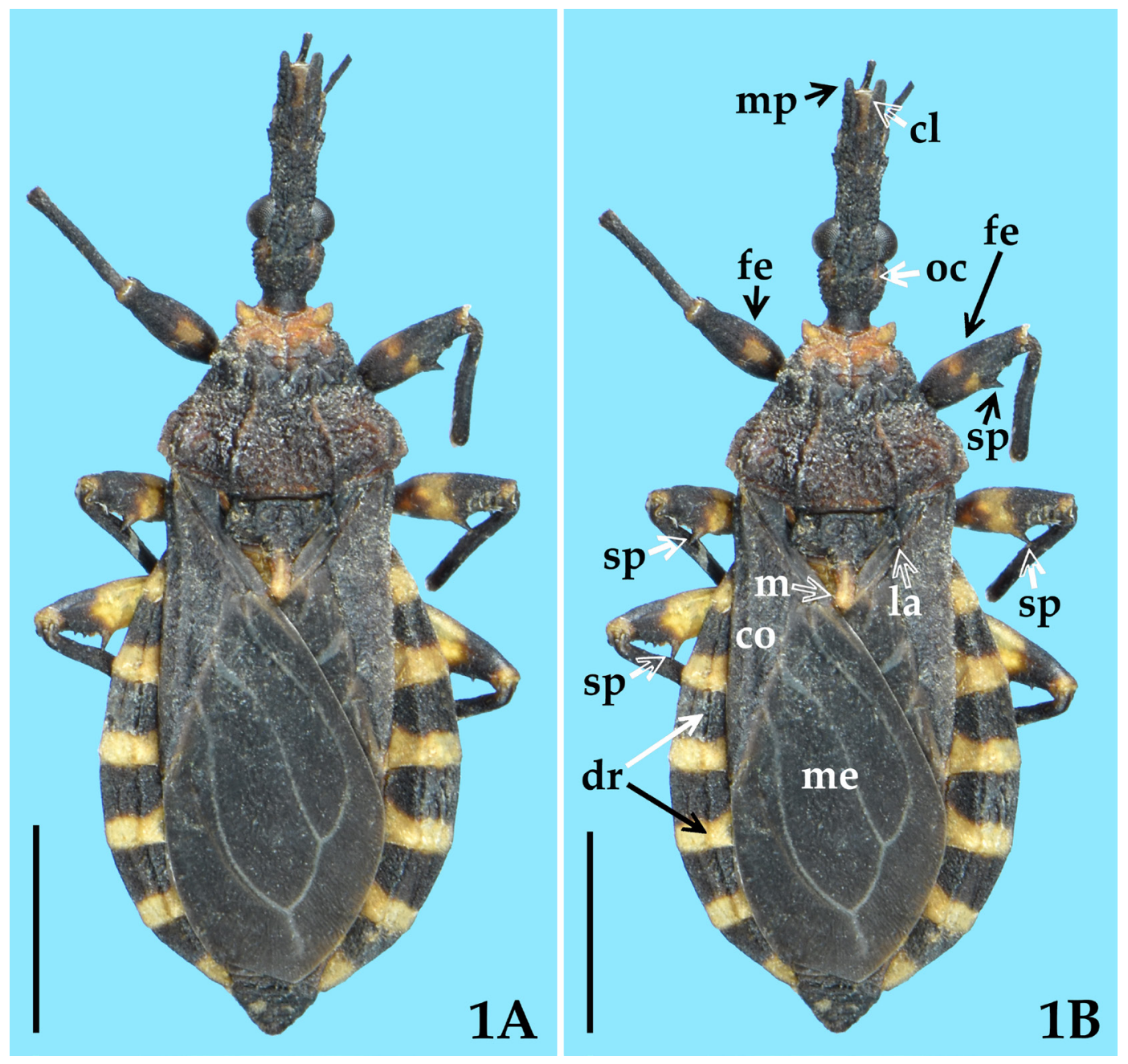

Figures 1A-1B. Belminus laportei, female from French Guiana, dorsal view. Scale bars: $2.0 \mathrm{~mm}$. B. Several diagnostic characters of the species indicated as follows: maxillary plates (mp) salient, large, projecting beyond apex of clypeus (cl); small, inconspicuous ocelli (oc); thickened femora (fe), which have spines (sp); scutellum with lateral subtriangular processes (la), besides the median posterior process $(\mathrm{m})$; connexivum with a dorsal longitudinal ridge (dr); hemelytra (formed by corium (co) and membrane (me) completely dark. / Belminus laportei, hembra de Guayana Francesa, vista dorsal. Escala: 2,0 mm. B. Caracteres de diagnóstico de la especie se indican a continuación: placas maxilares $(\mathrm{mp})$ salientes, grandes, que se proyectan más allá del ápice del clípeo (cl); ocelos pequeños y discretos (oc); fémures engrosados (fe), que tienen espinas (sp); escutelo con procesos subtriangulares laterales (la), además del proceso posterior mediano $(\mathrm{m})$; connexivum con una cresta longitudinal dorsal (dr); hemiélitro (formado por corium (co) y membrana (me) completamente obscuro. 

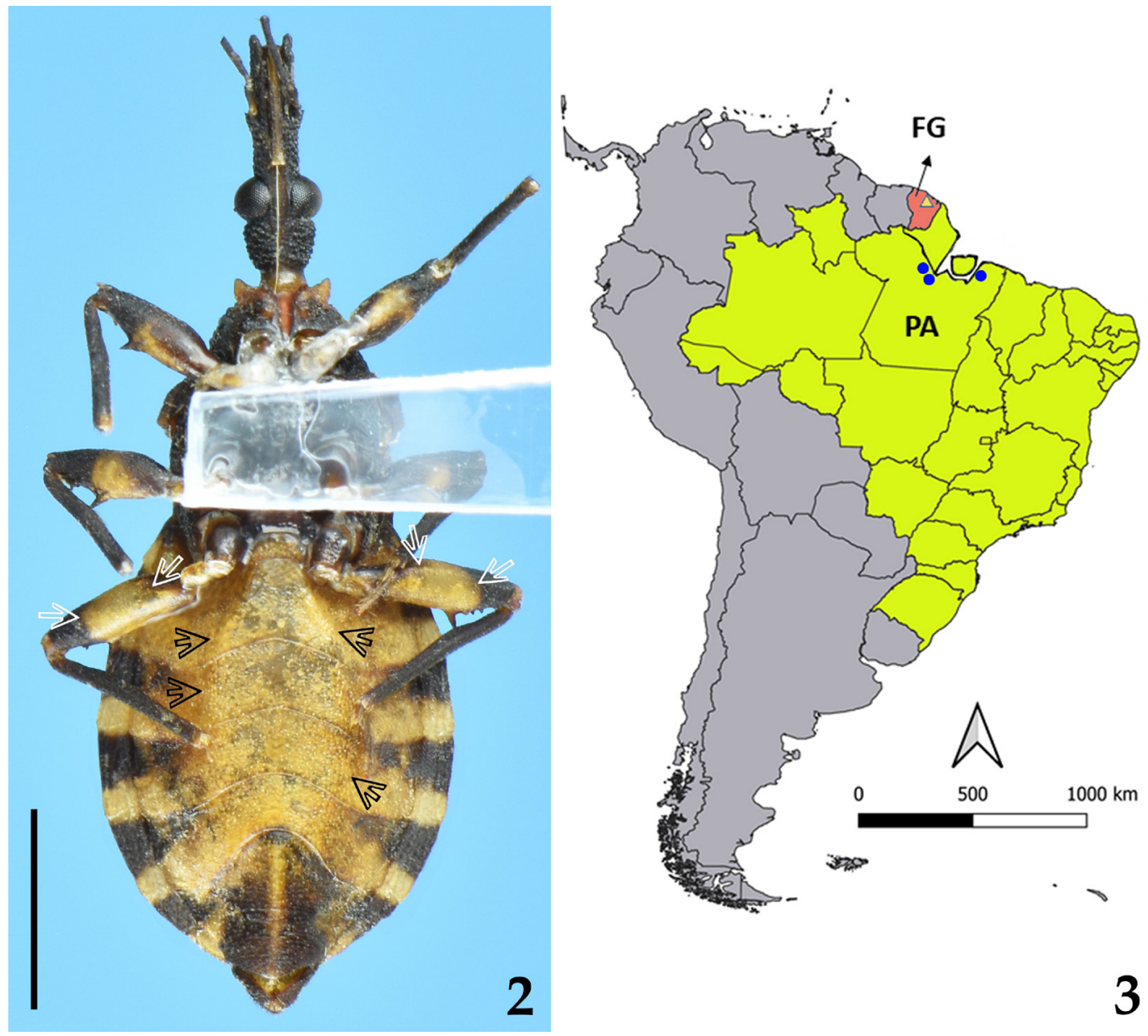

Figures 2-3. Belminus laportei, female from French Guiana, ventral view. Scale: $2.0 \mathrm{~mm}$. Two diagnostic characters of the species are indicated by white arrows (central two thirds of hind femora pale to pale yellowish) and black arrows (sternites abruptly flattened at center). 3. Points of occurrence of B. laportei in South America; Brazil (pale green color), French Guiana (pink color) and other countries (gray color); blue circles (previous records from state of Pará (PA), Brazil); yellow triangle (new record from French Guiana (FG). / Belminus laportei, hembra de Guayana Francesa, vista ventral. Escala: 2,0 mm. Dos caracteres de diagnóstico de la especie están indicados con flechas blancas (dos tercios centrales de los fémures posteriores de pálido a amarillento pálido) y flechas negras (esternitos abruptamente aplanados en el centro). 3. Puntos de ocurrencia de $B$. laportei en América del Sur; Brasil (color verde pálido), Guayana Francesa (color rosa) y otros países (color gris); círculos azules (registros anteriores del estado de Pará (PA), Brasil); triángulo amarillo (nuevo registro de Guayana Francesa (FG).

On the other hand, Bérenger et al. (2009) presented an exhaustive annotated list of Triatominae species of French Guiana, recording fourteen species to this country, including only one species of Bolboderini: Microtriatoma trinidadensis (Lent, 1951).

When examining a specimen of Bolboderini collected in French Guiana, the first author (HRG-S) identified it as a female of Belminus laportei. The complete collecting data are as follows: French Guiana, Bélizon, ix.1997, H. Gaspard leg. It is deposited in the Herman Lent Collection (under $\mathrm{N}^{\circ}$ 3460) of the Coleção de Triatomíneos do Instituto Oswaldo Cruz (CTIOC) (under $\mathrm{N}^{\circ}$ 13001), do Laboratório Nacional e Internacional de Referência 
em Taxonomia de Triatomíneos (LNIRTT) in Oswaldo Cruz Institute, Rio de Janeiro, Brazil.

The specimen was identified as Belminus laportei by consulting keys, diagnosis and descriptions available in the literature (Lent \& Wygodzinsky 1979; Lent et al. 1995; Sandoval et al. 2007; Galvão 2014), as well as a comparison with the holotype and a female paratype named as "allotype", which are deposited in the CTIOC and were examined by the first author (HRG-S). The characteristics presented by the specimen (Figs. 1-2) are entirely in accordance with these sources of information.

In short, the following characteristics allowed the identification of the specimen: a small triatomine (total length of $9.5 \mathrm{~mm}$ ) with a dorsoventrally compressed body; integument rugose covered by short setae; maxillary plates (=genae, auct.) salient, large, projecting beyond apex of clypeus; small, inconspicuous ocelli; short legs with thickened femora (corresponding to the tribe Bolboderini), which have spines; scutellum with lateral subtriangular processes, besides the median posterior process; connexivum with a dorsal longitudinal ridge; sternites abruptly flattened at center (corresponding to the genus Belminus); hemelytra completely dark; central two thirds of hind femora and most part of sternites pale to pale yellowish (corresponding to B. laportei).

Besides the fact that $B$. laportei was only found in three somewhat near localities in the same Brazilian state (Pará), it is noteworthy that, in two of them (Utinga and Monte Dourado), only one specimen was recorded (Lent et al. 1995), indicating that the species is somewhat rare. Therefore, although the present record of B. laportei to the French Guiana is based on only one specimen, it stands for the inclusion of this country in the area of geographical distribution of B. laportei (Fig. 3), increasing the number of triatomines recorded from French Guiana to fifteen.

Interestingly, Bérenger et al. (2009) stated that it would be very likely that other species besides those listed in their paper would be present in French Guiana, "particularly six species described in Brazil [Pará (PA), principally]", among which, B. laportei. Therefore, their hypothesis was herewith confirmed in relation to this species.

\section{Literature Cited}

Bérenger, J.-M., Pluot-Sigwalt, D., Pagès, F., Blanchet, D. and Aznar, C. (2009) The triatominae species of French Guiana (Heteroptera: Reduviidae). Memórias do Instituto Oswaldo Cruz, 104(8): 1111-1116.

Costa, J., Dale, C., Galvão, C., Almeida, C.E. and Dujardin, J.P. (2021) Do the new triatomine species pose new challenges or strategies for monitoring Chagas disease? An overview from 1979-2021. Memórias do Instituto Oswaldo Cruz, 116: e210015.

Galvão, C. (2014) Vetores da doença de chagas no Brasil. Sociedade Brasileira de Zoologia. Curitiba, Brasil. 289 pp.

Galvão, C. and Angulo, V.M. (2006) Belminus corredori, a new species of Bolboderini (Hemiptera: Reduviidae: Triatominae) from Santander, Colombia. Zootaxa, 1241: 61-68.

Galvão, C., Carvalho, R.U., Rocha, D.S. and Jurberg, J. (2003) A check-list of the current valid species of the subfamily Triatominae Jeannel, 1919 (Hemiptera, Reduviidae) and their geographical distribution, with nomenclatural and taxonomic notes. Zootaxa, 202: 1-36.

Lent, H. and Wygodzinsky, P. (1979) Revision of the Triatominae (Hemiptera: Reduviidae) and their significance as vector of Chagas disease. Bulletin of the American Museum of Natural History, 163: 123-520.

Lent, H., Jurberg, J. and Carcavallo, R.U. (1995) Belminus laportei sp. n. da Região Amazônica. (Hemiptera: Reduviidae: Triatominae). Memórias do Instituto Oswaldo Cruz, 90(1): 33-39. https: / / doi.org/10.1590/S0074-02761995000100008 
Monteiro, F.A., Weirauch, C., Félix, M., Lazoski, C. and Abad-Franch, F. (2018) Evolution, systematics, and biogeography of the Triatominae, vectors of Chagas disease. Advances in Parasitology, 99: 265-344. https: / / doi.org/10.1016/ bs.apar.2017.12.002

Sandoval, C.M., Pabón, E., Jurberg, J. and Galvão, C. (2007) Belminus ferroae n. sp. from the Colombian north-east, with a key to the species of the genus (Hemiptera: Reduviidae: Triatominae). Zootaxa, 1443: 55-64.

Zhao, Y., Galvão, C. and Cai, W. (2021) Rhodnius micki, a new species of Triatominae (Hemiptera, Reduviidae) from Bolivia. ZooKeys, 1012: 71-93. https:// doi.org/10.3897/ zookeys.1012.54779 